

\title{
The neural correlates of visual mental imagery: An ongoing debate.
}

Paolo Bartolomeo

\section{To cite this version:}

Paolo Bartolomeo. The neural correlates of visual mental imagery: An ongoing debate.. Cortex, 2008, 44 (2), pp.107-8. 10.1016/j.cortex.2006.07.001 . inserm-00239337

\section{HAL Id: inserm-00239337 https://www.hal.inserm.fr/inserm-00239337}

Submitted on 8 Apr 2008

HAL is a multi-disciplinary open access archive for the deposit and dissemination of scientific research documents, whether they are published or not. The documents may come from teaching and research institutions in France or abroad, or from public or private research centers.
L'archive ouverte pluridisciplinaire HAL, est destinée au dépôt et à la diffusion de documents scientifiques de niveau recherche, publiés ou non, émanant des établissements d'enseignement et de recherche français ou étrangers, des laboratoires publics ou privés. 


\title{
The neural correlates of visual mental imagery: an ongoing debate
}

\author{
Paolo Bartolomeo \\ Inserm Unit 610, Department of Neurology AP-HP, IFR70, Hôpital de la Salpêtrière, and \\ Université Pierre et Marie Curie-Paris6, Paris, France
}

Correspondence address:

Paolo Bartolomeo

INSERM Unit 610

Pavillon Claude Bernard

Hôpital Salpêtrière

47 bd de l'Hôpital

F-75013 Paris - France

Tél. +33 (0)1 42160025 or 58

FAX +33 (0) 142164195

paolo.bartolomeo@chups.jussieu.fr

http://marsicanus.free.fr/

ABSTRACT - The functional mechanisms and the neural correlates of visual mental imagery (the faculty whereby we can use our "mind's eye” to visualize objects in their absence) are at the centre of a lively debate in cognitive neuroscience. Neurocognitive models have proposed a functional equivalence between visual perception and visual mental imagery, which would be subserved by common neural substrates, such as the retinotopic areas in the occipital lobe. However, brain-damaged patients may demonstrate either impaired imagery and preserved perception, such as the classical Charcot and Bernard case and the patients described by Moro et al. (2008, this issue), or the opposite pattern of performance, consisting of preserved imagery and impaired perception. This double dissociation provides a strong challenge to models postulating a functional and anatomical equivalence of perception and imagery, and suggests that these functions have partly distinct neural correlates. 
In 1883, Bernard reported "a case of sudden and isolated suppression of the mental vision of signs and objects (form and colour)”, which came under Charcot's observation in the Salpêtrière Hospital in Paris (Charcot \& Bernard, 1883). M. X, a well-learned polyglot, used to experience particularly vivid visual mental images for object forms and colours, which he described as being precise and glowing as reality itself. M. X employed these capacities as a mnemothecnics. For example, he could immediately retrieve the visual appearance of a letter he had received in its minimal details, including writing irregularities and erasures. By “reading” these mental images, he could easily recall all the content of his large correspondence. In a similar way, he could “read” from memory the first book of Iliad in ancient Greek. He travelled frequently, and used to draw accurate and detailed sketches of landscapes he had seen just once. One day, M. X found himself to be completely unable to recall forms and colours from memory. Each time he went back to his hometown, he stared in amazement at streets and monuments, which looked unfamiliar to him, but was eventually able to find his way home. Asked to describe the principal place of his hometown, he answered: “I know it exists, but cannot imagine it or say anything about”. He could not draw anymore from memory in his former, detailed fashion; now, he only produced rough sketches. He perfectly remembered that his wife had black hair, but repeatedly complained of being unable to visualize it. Now he just recalled a few verses from Iliad, and had to look for information in his correspondence by searching the real letters ("as all of us do", was Charcot's comment). Ophthalmologic examination, made by Dr Parinaud, only revealed myopia and a slight decrease in colour perception. M. X’s only perceptual problems appeared to consist in a minor reading impairment for some orthographic material; he was unable to recognize some Greek letters on visual presentation, unless he traced them with his finger. Charcot comments that "he has to compensate with his hand his moderate impairment of the visual memory of words”. No other neurological deficit was observed. Charcot and Bernard 
concluded that memory is not a unitary faculty, but has modality-specific components, which can be selectively impaired, as it was the case for M. X's "visual memory". No evidence was available about the locus of lesion in this patient, but his reading problems in the absence of more elementary visual impairment might suggest left temporal damage with sparing of the occipital cortex. Indeed, another patient, VSB, with extensive damage to the left temporal and parietal lobes and no occipital involvement (Bartolomeo et al., 2002), showed both pure alexia and an inability to retrieve the visual features of letters and words, unless he was allowed trace them with his finger, and was thus similar in this respect to M. X. Charcot and Bernard's remarkable description is the first of a series of reports of dissociations between impaired visual mental imagery and (relatively) preserved visual perception (reviewed in Bartolomeo, 2002). When anatomical information is available, extensive damage to the left temporal lobe seems to be the rule in these cases. On the other hand, perusal of the literature indicates that damage to the occipital lobes may well produce perceptual deficits, but seems neither necessary nor sufficient to impair visual mental imagery.

Moro et al.’s (2008, this issue) detailed report of two patients with traumatic brain injury makes a further, compelling case for this lesional correlation. Both patients had impaired visual mental imagery with reasonably preserved perception, and in both cases there was an involvement of the left temporal lobe in the absence of visible damage to the occipital cortex. The reported evidence nicely complements the opposite dissociation (impaired perception with preserved imagery) found in patients with more posterior lesions involving the occipital lobe (e.g., Bartolomeo et al., 1998; Chatterjee \& Southwood, 1995). A novel and appealing feature of the Moro et al's study is the assessment of non-visual forms of imagery. Patients had spared auditory, gustatory, olfactory and motor imagery. Tactile imagery was preserved in one patient. The relative preservation of non-visual imagery supports the important point made by Charcot and Bernard, that imagery abilities may be modality- 
specific. It is a pity that imagery for faces was not assessed; this might have provided evidence relevant to the hypothesis that different aspects of face imagery may be differentially affected by left or right temporal lesions (Barton \& Cherkasova, 2003).

The double dissociation between perceptual and imagery abilities, with highly consistent lesional correlates, provides strong evidence against the claim that visual mental images are, as it were, “displayed” on a visual buffer consisting of topographically organized areas in the occipital lobe (see Kosslyn et al., 2006, p. 18).

Shall we conclude that visual mental images are stored in the left temporal lobe? Not necessarily. Neuroimaging results suggest that visual mental imagery requires large networks of brain areas, including top-down influence from frontal and parietal regions to the temporal lobe (Mechelli et al., 2004). Traumatic brain injuries, like those suffered by Moro et al.’s patients, typically provoke diffuse axonal injury, which is likely to disrupt large-scale brain networks. Detailed anatomical study of future cases of imagery deficits, together with advancing knowledge of brain connectivity (Mesulam, 2005), are likely to identify more precisely the neural correlates of "the mind's eye”.

\section{References}

Bartolomeo, P. (2002). The relationship between visual perception and visual mental imagery: a reappraisal of the neuropsychological evidence. Cortex, 38(3), 357-378.

Bartolomeo, P., Bachoud-Lévi, A. C., Chokron, S., \& Degos, J. D. (2002). Visually- and motor-based knowledge of letters: evidence from a pure alexic patient. Neuropsychologia, 40(8), 1363-1371.

Bartolomeo, P., Bachoud-Lévi, A. C., de Gelder, B., Denes, G., Dalla Barba, G., Brugières, P., et al. (1998). Multiple-domain dissociation between impaired visual perception and preserved mental imagery in a patient with bilateral extrastriate lesions. Neuropsychologia, 36(3), 239-249.

Barton, J. J. S., \& Cherkasova, M. (2003). Face imagery and its relation to perception and covert recognition in prosopagnosia. Neurology, 61(2), 220-225.

Charcot, J. M., \& Bernard, D. (1883). Un cas de suppression brusque et isolée de la vision mentale des signes et des objets (formes et couleurs). Le Progrès Médical, 11, 568571.

Chatterjee, A., \& Southwood, M. H. (1995). Cortical blindness and visual imagery. Neurology, 45, 2189-2195. 
Kosslyn, S. M., Thompson, W. L., \& Ganis, G. (2006). The Case for Mental Imagery. New York: Oxford University Press.

Mechelli, A., Price, C. J., Friston, K. J., \& Ishai, A. (2004). Where bottom-up meets topdown: Neuronal interactions during perception and imagery. Cerebral Cortex, 14(11), 1256-1265.

Mesulam, M.-M. (2005). Imaging connectivity in the human cerebral cortex: The next frontier? Annals of Neurology, 57(1), 5-7.

Moro V., Berlucchi G., Lerch J., Tomaiuolo F., \& Aglioti S. M. (2008). Selective deficit of mental visual imagery with intact primary visual cortex and visual perception. Cortex, 44: 109-118. 